Received: 19.8.2020; Revised: 23.11.2020; Accepted: 20.12.2020; Published online: 22.12.2020

\title{
CONSEQUENCES OF COVID-19 ON DIGITAL ECONOMY IN THE HORN OF AFRICA
}

\author{
Saleamlak Fentaw GETAHUN *1 (iD), Sintayehu DEJENE 2 (iD
}

\author{
Address: \\ ${ }^{1}$ Haramaya University, College of Agriculture and Environmental Sciences, School of Agricultural Economics and \\ Agribusiness, Dire Dawa, Ethiopia \\ ${ }^{2}$ Haramaya University, College of Agriculture and Environmental Sciences, School of Animal and Range Sciences, \\ Dire Dawa, Ethiopia \\ * Corresponding author: $\underline{\text { salefen@ mail.com }}$
}

\begin{abstract}
Research background: The Horn of Africa is arguably the most vulnerable region for many shocks. Currently, the coronavirus disease-2019 (COVID-19) is spreading fast in the region. The number of new cases and the mortality of this pandemic have increased dramatically. As lockdown and movement restrictions are the major strategies suggested to minimize the spread of the virus, the impacts of the COVID-19 pandemic are not only limited to public health but also have a major impact on the economic aspects.

Purpose of the article: This review paper aims to synthesize the consequences of COVID-19 on the digital economy in the Horn of Africa. We review and recommend adopting the digital economy could be the remedy to go through COVID-19 safely as the world sees digital companies boom during the pandemic.

Methods: To achieve our purpose, we applied qualitative analysis and synthesis as a method, and recently published papers in the area (most suitable to our aim) are included as data sources.

Findings \& Value added: The Horn region is already feeling the economic impact of the virus and we discussed it in terms of monetary, fiscal, current account balance, and unemployment expected impacts. However, this pandemic is not just about adverse impacts; it is also about unanticipated business opportunities. In this perspective, the decline of the international oil price during this pandemic can be seen as a blessing in disguise since countries in the region are net importers of crude oil. Moreover, Ethiopia's coffee export has increased rapidly at a level of record sales of about 665 million dollars from July 2019 to April 2020 (10 months' export). The lion's share of this upsurge has been achieved because of the rise in the coffee consumption from homes of the country's Arabic coffee importers, such as Germany, the U.S, and Saudi Arabia due to the lockdown measures. The paper also covers the prospects of the virus by pinpointing various booming companies that are digital-based businesses. Therefore, we urge the Horn of African countries to internalize these opportunities by swiftly investing in the telecom sector to shift to the online way of doing business.
\end{abstract}

Keywords: COVID-19; economic impact; digital economy; Horn of Africa

JEL: F40; F62; I18

\section{INTRODUCTION}

Since the dawn of human civilization, our world has gone through myriad forms of unprecedented calamities; from deadly pandemics to devastating wars. Currently, the coronavirus pandemic is threatening the world in all aspects including economic turmoil. The world economy is being tremendously hit by the prevalence of the disease especially after the lockdown measures taken by respective governments (Sumner et al., 2020). Unemployment has skyrocketed, growth rates have plummeted, and hunger is looming in poor countries (Loayza and Pennings, 2020). As estimated by the United Nations Economic Commission for Africa (Payne, 2020), for instance, the continent will observe at least a 1.4 percentage point Gross Domestic Product (GDP) decline equivalent to \$29bn even though a GDP forecast is dubious when the virus trajectory is unknowable (Carlsson-Szlezak et al., 2020).

The scale of the problem could be significant especially in Sub-Saharan African countries which would also be exacerbated by the already existing poor conditions. Most people are used to live on a daily basis particularly in urban areas of these countries with no savings. This subsistence way of living could trigger imminent hunger and food insecurity. For example, the Food Security Information Network (FSIN) (2020) has forecasted that hunger would be imminent at biblical proportions in the Horn of Africa which is thought to be a reasonable prediction.

Since COVID-19 was first reported in the Horn of Africa in March 2020, the virus has caused more than 170 deaths with over 9910 cases in the region as of June 12, 2020. The number of new confirmed cases is relatively low compared to other regions in Africa, but recent figures continue to increase daily. For instance, on May 22, 2020, 223 new cases and 10 deaths were recorded in Djibouti. In Ethiopia, a record of 245 new cases documented on June 12, 2020 (Worldometer, 2020). Governments in the region moved swiftly to take measures to control the 
spread of the disease, including the closure of international borders and schools, movement restrictions, curfews, and lockdowns. Gathering for social or religious reasons have also been restricted. Restrictions on transport services continue on the number of passengers allowed per vehicle. Even if the number of confirmed cases and deaths associated with COVID-19 is low, its impacts will be multiple, one of which will be heightened economic impact. Therefore, it is vital to examine the economic impact of COVID-19 for future suggestions. Thus this synthesis paper aims to analyse and summarize the adverse economic impacts of the pandemic and digital business opportunities to be exploited in the region. To achieve the objectives of this review article, we applied qualitative methods and included the most recent peerreviewed articles as data sources.

\section{LITERATURE REVIEW}

The Horn of Africa is located in the easternmost point of the African continent (Figure 1) and for this article, it is defined as the region that is home to the countries of Djibouti, Eritrea, Ethiopia, and Somalia, whose cultures have been linked throughout their long history. The region covers approximately 2 million $\mathrm{km} 2$ and is inhabited by roughly 115 million people (Ethiopia: 96.6 million, Somalia: 15.4 million, Eritrea: 6.4 million, and Djibouti: 0.81 million). Currently, Horn of Africa countries are in a fragile state in terms of economy, security, and political transformation or have been severely weakened by internal war and government failures. Prolonged armed conflict, drought, and insecurity are very common. They possess neither the capacity to contain the COVID-19 pandemic nor to mitigate the resulting unemployment, poverty, and hunger. Currently, one-third of the population of Somalia depends on food aid and around 3.6 million have been displaced due to war or drought. Another challenge in the region is the high population density in the urban areas for instance in Ethiopia and a large number of day-labourers in the informal sector with no savings and poor healthcare services, are particularly at risk from COVID-19.

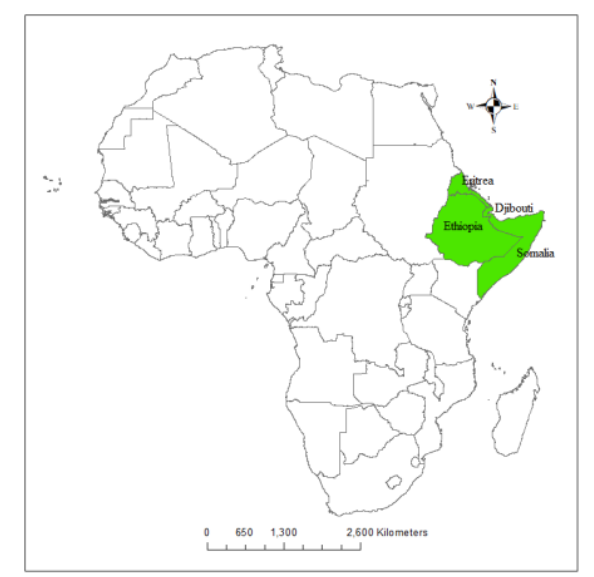

Figure 1: Location of Horn of Africa

\section{The Economy of Horn of Africa}

The Horn of Africa is one of the poorest regions, in terms of economic measurements, in the world with a total GDP of about 107.42 billion dollars of which Ethiopia takes the lion's share with 91.17 billion dollars (about $85 \%$ of total nominal GDP of the Horn) even though Djibouti tops the group by per capita income parameter with about 2,936 US dollars (WB, 2019). Member countries' economy is mainly made up of agriculture and related livelihoods such as livestock export with an average GDP growth rate of 7.7\% for the last decade (United Nations, 2019). While agriculture's share in GDP has fallen recently, the service sector is taking the larger share of the GDP which indicates some sign of the structural transformation of the region's economy that is especially evident in Ethiopia.

Djibouti's economy, from the supply side, mainly depends on trade with Ethiopia, which accounts for $80 \%$ of Djibouti's port activities (African Development Bank - ADB, 2020). The two countries are highly connected by using the same seaport since Ethiopia is a landlocked country. From a demand point of view, Djibouti's economy is driven by public investment in rail and port infrastructure which also targets to easing business with Ethiopia.

Mining and agriculture remained the dominant contributors to real GDP growth on the supply side of the Eritrean economy. On the demand side, government investment in infrastructure-notably in energy, roads, and irrigation-underpins growth (ADB, 2020).

On the supply side, service, agriculture, and industry are the three major sectors contributing $39.6 \%, 33.3 \%$, and $27.1 \%$ to the national income of Ethiopia, respectively (National Bank of Ethiopia - NBE, 2019). The industry was driven by construction, notably for industrial parks and infrastructure investments. Structural transformation is underway but needs to accelerate. While agriculture's share in GDP has fallen, the sector still employs more than $70 \%$ of Ethiopia's workforce, and manufacturing accounts for less than $10 \%$ of GDP (ADB, 2020). On the demand side, private consumption and domestic investment were the primary growth drivers in 2019.

Remittances, livestock exports, and retail imports account for the bulk of economic activity in Somalia. Livestock is estimated to contribute over $40 \%$ of GDP and over $50 \%$ of export earnings. The economy grew by an estimated 2.9\% in 2019, up from 2.8\% in 2018 (Boote, Byrne and Babay, 2020). The rebound is mainly due to recovery in agriculture and strong consumer demand. Inflation peaked at $5.1 \%$ in 2018 and declined to an estimated $4.4 \%$ in 2019 as food prices adjusted downward (ADB, 2020). According to this source, the government budget remained in balance, given the restrictions on new public borrowing under staff monitored programs (SMPs) since 2016 and the need to keep inflation under control.

\section{Digital Economy and its development in the Horn of Africa}

Various scholars tried to define what does it mean by the 'digital economy' (e.g. Barefoot et al., 2018; Carlsson, 2004; Gumah and Jamaluddin, 2006) since the digital economy was first coined in the mid-'90s. However, there is no a generally accepted definition in the literature since any previous definition gets older soon in this dynamic new economy. In this regard, we endorsed the definition by Knickrehm et al. (2016) which encompasses many 
parts of digitization. According to these authors, the digital economy is: "the share of total economic output derived from a number of broad "digital" inputs. These digital inputs include digital skills, digital equipment (hardware, software, and communications equipment), and the intermediate digital goods and services used in production. Such broad measures reflect the foundations of the digital economy".

According to Bukht and Heeks (2018), the digital economy makes up around 5\% of global GDP and 3\% of global employment. The digital economy is growing fast, especially in developing countries as the rate of growth estimated to be $15-25 \%$ per year albeit the global North has had the lion's share of this economy to date.

The Horn of Africa is one of the least connected regions in the world and digital economy is in its infant stage in the region (Gagliardone and Stremlau, 2011). However, recently, the region is quickly investing in the Internet sector to transform the economy to digitization. It has fewer legacy challenges to deal with and is therefore adopting digitized solutions faster out of necessity and the current moment also offers a leapfrogging opportunity (AU, 2015). The number of mobile and internet users is increasing fast in this region which paves the way to digital transformation. All member states are striving to develop an internet connection and other infrastructures needed to vitalize the digital economy. For example, the government of Ethiopia and Alibaba Group sign agreements to establish eWTP Ethiopia Hub in November 2019. The country aims to build a dynamic and growing digital economy that contributes significantly to overall economic growth.

\section{COVID-19 AND ECONOMIC ACTIVITIES IN THE HORN OF AFRICA}

The number of new cases and mortality of COVID-19 have significantly increased in the Horn of Africa. The virus seems to be transmitted from person to person mainly via small respiratory droplets through sneezing, coughing, or when people interact with each other (CDC, 2020). Thus, lockdowns and movement restrictions are the major strategies used in the Horn of Africa for fighting the pandemic (Weber, 2020). This approach aims to reverse epidemic growth, reducing case numbers to low levels by social distancing the entire population, closing schools and universities, and halting all non-essential economic activities (CDC, 2020). However, Pandemic-related lockdowns and spatial distancing are impacting economic sustainability and well-being (Amewu et al., 2020). Moreover, the economies of the region rely heavily on primary commodity exports including coffee, livestock, and livestock produce and vegetables, for which market value is collapsing due to measures taken to fight the disease and lack of frequent interactions for incomegenerating activities.

In writing this paper, we used a qualitative systematic review, which can be described as a method of comparing and synthesizing findings from qualitative studies. That is, a strict systematic review process is used to collect articles, and then a qualitative approach is used to assess them. We also used the inclusion and exclusion criteria of articles. Only peer-reviewed articles collected from Google Scholar, based on our keywords, are selected.

\section{ECONOMIC IMPACT OF COVID-19 IN THE HORN OF AFRICA}

The economic impact of COVID-19 in the Horn of Africa region is multifaceted with monetary impacts, fiscal impacts, unemployment, and adverse impacts on the aviation sector which in turn puts pressure on the current account balance. Such crises may lead the region to political unrest. However, there are also some unanticipated opportunities that governments of this region should respond quickly. This part, therefore, aims to summarize the adverse economic impacts of the pandemic and to review the unanticipated business opportunities which may offset some of the losses.

COVID-19 is most definitely spreading economic suffering globally and the virus may be as infectious economically as it is medically (Baldwin and Mauro, 2020). According to Rodela et al. (2020), the economic implications related to COVID-19 in developing countries include a high health-related cost, high out-of-pocket expenses, the added burden of non-communicable diseases, missed economic opportunities, and socioeconomic consequences like unemployment and poverty.

The situation is worse in the Horn of Africa because of a desert locust invasion and other pressing problems such as climate change and migration (United $\boldsymbol{e t}$ al., 2020). The region may struggle a lot in combating the two current human and crop infections, the coronavirus, and the locust invasion respectively. According to Weber (2020), lockdowns and border closures will mean that economies that are already weak will face more overwhelming challenges and will slip into recession.

About half of gross national product (GNP) is generated in cities of the Horn despite a large portion of the population employs in agriculture (Weber, 2020), which indicates how the urban economy could be impacted due to the lockdown. The service sector has been one of the urban key sectors contributing to the fast economic growth during the last few decades in the Horn region. This sector, for instance, contributes about $40 \%$ of Ethiopian GDP. Ironically, the same sector has been arguably the most stricken by the coronavirus pandemic. For example, hotels and restaurants are being closed, flights are being cancelled, and tourism is being halted which in turn forced firms to dismiss most of their employees.

Regional trade in goods, although small, has also been restricted by the COVID-19 measures. When Somalia closed its border, trade in the common stimulant Khat (Catha edulis) collapsed, and Ethiopian cultivators were left without any income. Moreover, producers of this commercial crop in eastern Ethiopia used to daily export to Djibouti have been impacted significantly. As stated earlier, the pandemic affects the economy through four impact mechanisms: monetary, fiscal, current account balance, and unemployment impacts (United et al., 2020).

Monetary impacts: sufficient food availability, production, and supply have been disrupted because of the 
lockdown, stay-home, and social distancing measures; the coronavirus pandemic could lead to demand-pull inflation and volatility of the exchange rate because of less export. This scenario will have led to rising food costs and tremendously affect lower-income families and senior citizens (McKibbin and Fernando, 2020). Since the above measures are more or less being taken in all the four Horn of Africa countries (Djibouti, Eritrea, Ethiopia, and Somalia), the monetary impact will also be more or less the same.

Fiscal impacts: the economic downturn is expected to reduce the GDP which will, in turn, reduce government revenue through less tax. Somalia could be the most impacted country from the Horn region that its authorities are forecasting a contraction of $35-45 \%$ of GDP (Babay et al., 2020). It is also estimated that COVID-19 will shave 2.9 percentage points off this fiscal year's economic growth in Ethiopia (UN ECA, 2020). This could also translate into potential reductions in external assistance as donor countries are also affected, which means fewer funds for child-focused social sectors and less space to increase public spending both for the longer term and for current spending in response to the COVID-19 emergency.

Pressure on the current account balance: the aviation sector is one of the most affected and African giants like Ethiopian Airlines lost $\$ 550$ million because of international flight restrictions due to the COVID-19 pandemic. Adverse impact on the aviation sector will mean less foreign exchange earnings required for muchneeded imports, plus hits on remittances, and the tourism sector will also affect foreign exchange earnings. This will hinder the ability to service debt payments. Increase the level of debt today implies a mortgaging of the future. Borrowing today often implies taking from today's children and adolescents who will have to repay the debts tomorrow.

Unemployment and poverty: It is estimated that employment in the African continent will plummet to 48 percent due to the reduction in production of which the Horn region may owe a larger share (AU, 2020). Any restriction related to the COVID-19 pandemic in the Horn limit the ability to work on daily bases and earn a living, particularly for daily labourers and informal workers who are mainly women and account for about $89 \%$ of all employment in the Horn of Africa, will put a strain on families. The precarious character of those work, as evidenced by the absence of a formal contract, means that their sources of livelihood may be impacted significantly by the COVID-19 pandemic due to lockdown and movement restriction which in turn lead to an unprecedented amount of people into poverty trap (Lone and Ahmad, 2020).

The COVID-19 pandemic is not just about the adverse effect on the economy; it is also about unanticipated opportunities. In this perspective, the decline of the international oil price during this pandemic can be seen as a blessing in disguise since countries in the region are net importers of crude oil. Moreover, Ethiopia's coffee export has increased dramatically at a level of record sales of about 665 million dollars from July 2019 to April 2020 (10 months' export) based on the public media outlet. This rise has been achieved because of the upsurge in the consumption of coffee drinks from the homes of Ethiopia's Arabic coffee importers such as Germany, the U.S, and Saudi Arabia due to the lockdown measures.

\section{CONCLUSIONS AND RECOMMENDATIONS}

Digital technologies have become a critical enabler of connectivity facilitating the continuity of our regular lives and connecting people more than ever before during the global pandemic. More people have turned to their computers and smartphones as a lifeline and tools to substitute their in-person activities online as cities and countries have been asking the population to stay at home (ITU, 2020).

The global crisis is hurting business but not all companies are losing out (Baldwin and Mauro, 2020). There are some modern sectors immune from the pandemic so that people in the Horn of Africa should take advantage of them. According to various sources, virtual businesses are not just resilient to the lockdown because of the pandemic but they are also booming sectors (e.g. Buheji and Ahmed, 2020; Ranasinghe et al., 2020; Surico and Galeotti, 2020). For instance, video conferencing companies like Zoom, online shopping companies like Amazon, online fitness classes, home delivery restaurants, TV shows, and movies, and YouTubers are on the top of the list including other businesses with forward and backward linkages to the mentioned companies.

Unfortunately, these types of businesses are not common in the Horn region due to the limitation of ICT infrastructure. However, if different countries in the region commit themselves to exploit this opportunity, they should increase investment in the telecom sector to expand more prudent internet connection. Moreover, governments of these countries encouraged to free regulations related to the hindrance of private sector participation in the industry. In this regard, Ethiopia is epitomized by having a single state-driven telecommunication firm that monopolizes all telecom related services in the country so that quality service provision is one of the lowest in the region. Consequently, Prime Minister Abiy Ahmed's regime is in the process to give a license for two private telecom firms to ameliorate service delivery by the industry.

History suggests that the global economy after a major crisis like COVID-19 will likely be different in several significant ways (Carlsson-Szlezak et al., 2020). The authors explicitly name these ways as a microeconomic legacy, macroeconomic legacy, and political legacy. By explaining the microeconomic legacy, they epitomize the adoption of new technologies and crisis-driven business models such as the adoption of online shopping among Chinese consumers which in turn enhanced the rise of Alibaba after the SARS outbreak of 2003.

Likewise, the Harvard Business School experts expect some change of business practice after the COVID-19 pandemic (Gerdeman, 2020). Business, as usual, may not be the way forward as of post-COVID-19. This is one of the visible opportunities that the Horn region should exploit. Since most of the population is youth in the 
region, the learning curve would be steeper if considerable effort will be exerted in ICT training and education.

The training will help the youth in how to do business online by using the internet which will be the new way of doing business during and after this pandemic which otherwise has been considered as a luxury. Accordingly, some skills are especially required for foreseeing prospects after the virus. Automated jobs will be in demand as companies are predicted to change business practices from the traditional office setup to remote working. Therefore, coding, digital marketing, closing a deal via phone, copywriting, and project management are some of the skills forecasted to be essential.

COVID-19 is affecting the world economy indiscriminately. However, economies of precarious states like the Horn African countries are being impacted more severely because they possess neither the capacity to contain the pandemic nor to mitigate the resulting unemployment, poverty, and hunger. Unless integrated solutions would be taken to reduce the impact, many vulnerable people will slip into poverty and starve to death. The existing poor macroeconomic situations would also worse. The budget deficit that would have been traditionally serviced from external sources including foreign aid may not be possible because of the virus's universal adverse impacts.

On top of the adverse economic impacts, there are also unanticipated business opportunities. The fall in the price of oil could have positive effects, for example by lowering fuel prices in the Horn region. Demand for some export commodities like Ethiopian Arabic coffee has increased dramatically because of coffee consumption surge from the import side. Moreover, there are also digital-based booming companies during the pandemic which should quickly be adopted in the Horn of Africa. Therefore, we recommend policymakers to adopt the online way of doing business by reinforcing investment in the telecom sector to swiftly shift to the digital economy.

\section{REFERENCES}

ADB. African development bank. (2020). African economic outlook. Annual yearly review study. https://doi.org/10.1373/clinchem.2007.093781

AMEWU, S., ASANTE, S., PAUW, K., \& THURLOW, J. (2020). The economic costs of covid-19 in SubSaharan Africa: insights from a simulation exercise for Ghana. European Journal of Development Research. https://doi.org/10.1057/s41287-020-00332-6

AU. African union. (2015). The digital transformation strategy for Africa (2020-2030). 739(April), 1-46.

AU. African union. (2020). Impact of the corona virus (Covid 19) on the African Economy. https://au.int/sites/default/files/documents/38326-doccovid-19 impact_on_african_economy.pdf

BALDWIN, R., \& MAURO, B. W. DI. (2020). Economics in the time of COVID-19. Economics in the time of COVID-19. www.cepr.org

BAREFOOT, K., CURTIS, D., JOLLIFF, W. A., \& NICHOLSON, J. R. OMOHUNDRO, R. (2018). Defining and measuring the digital economy. US
Department of Commerce Bureau of Economic Analysis, Washington, DC. WP2018-4. p. 1-24.

BOOTE, S, BYRNE, K, \& BABAY, I. (2020). Economic impacts of and policy responses to the coronavirus pandemic: early evidence from Somalia. Supporting economic transformation. Overseas development institute. $\quad$ https://set.odi.org/wpcontent/uploads/2020/04/Economic-impacts-of-andpolicy-responses-to-the-coronavirus-pandemic-earlyevidence-from-Rwanda.pdf

BUHEJI, M., \& AHMED, D. (2020). Foresight of coronavirus (COVID-19) Opportunities for a better world. American Journal of Economics, (2), 97-108. https://doi.org/10.5923/j.economics.20201002.05

CARLSSON, B. (2004). The Digital Economy: What is new and what is not? Structural Change and Economic Dynamics, 15(3), 245-264. https://doi.org/10.1016/j.strueco.2004.02.001

CARLSSON-SZLEZAK, P., REEVES, M., \& SWARTZ, P. (2020). What coronavirus could mean for the global economy. Harvard Business Review, March, 3. https://hbr.org/2020/03/what-coronavirus-couldmean-for-the-global-economy

CDC. Centers for disease control and prevention. (2020) News releases CDC. Online Newsroom CDC. https://www.cdc.gov/

FSIN. food security information network. (2020). Global report on food crises. 202 pp. https://www.fsinplatform.org/sites/default/files/resour ces/files/GRFC 2019-Full Report.pdf

GAGLIARDONE, I., \& STREMLAU, N. (2011). Mapping digital media: digital media, conflict and diasporas in the horn of Africa. Open Society Foundations, 16.

GERDEMAN, D. (2020). How the coronavirus is already rewriting the future of business - Harvard Business School Working Knowledge. In Harvard Business School. https://hbswk.hbs.edu/item/how-thecoronavirus-is-already-rewriting-the-future-ofbusiness

GUMAH, M. E., \& JAMALUDDIN, Z. (2006). What is the digital economy, and how to measure it. $E$ Proceedings of Knowledge Management International Conference and Exhibition.

ITU. International Communication Union. (2020). Economic impact of COVID-19 on digital infrastructure Report of an Economic Experts Roundtable organized by ITU. https://www.itu.int/dms_pub/itu-d/opb/pref/D-PREFEF.COV_ECO_IMPACT-2020-PDF-E.pdf

KNICKREHM, B. M., BERTHON, B., \& DAUGHERTY, P. (2016). Digital disruption: The growth multiplier Optimizing digital investments to realize higher productivity and growth. Accenture. https://www.accenture.com/_acnmedia/pdf14/accenture-strategy-digital-disruption-growthmultiplier-brazil.pdf

LOAYZA, N. V., \& PENNINGS, S. (2020). Macroeconomic Policy in the Time of COVID-19. Macroeconomic Policy in the Time of COVID-19. World Bank. https://doi.org/10.1596/33540 
LONE, S. A., \& AHMAD, A. (2020). COVID-19 pandemic-an African perspective. Emerging Microbes and Infections, 9(1), 1300-1308. https://doi.org/10.1080/22221751.2020.1775132

MCKIBBIN, W. J., \& FERNANDO, R. (2020). The global macroeconomic impacts of COVID-19: Seven Scenarios. SSRN. https://doi.org/10.2139/ssrn.3547729

NBE. National bank of Ethiopia. (2019). Ethiopia: macroeconomic and social indicators. National Bank of Ethiopia Quarterly Bulletin. https://nbebank.com/quarterly-bulletin/

PAYNE, C. (2020). COVID-19 in Africa. Nat Hum Behav 4, 436-437. https://doi.org/10.1038/s41562020-0870-5

RANASINGHE, R., KARUNARATHNE, C., \& PRADEEPAMALI, J. (2020). After corona (Covid 19) impacts on global poverty and recovery after corona (Covid 19) impacts on global poverty and recovery of tourism based service economies: an appraisal. Journal of Management and Tourism Research, 3(1), pp. $v$-xix. https://doi.org/10.13140/RG.2.2.26187.34087

RODELA, T. T., TASNIM, S., MAZUMDER, H., FAIZAH, F., SULTANA, A., \& HOSSAIN, M. (2020). Economic Impacts of Coronavirus Disease (COVID-19) in Developing Countries. Working paper. https://doi.org/10.31235/osf.io/wygpk

SUMNER, A., HOY, C., \& ORTIZ-JUAREZ, E. (2020). Estimates of the impact of COVID-19 on global poverty. WIDER Working Paper 2020/43. https://doi.org/10.35188/UNU-WIDER/2020/800-9
SURICO, P., \& GALEOTTI, A. (2020). The economics of a pandemic: the case of Covid-19. London Business School Lecture, March, 3, 4. https://www.london.edu/think/the-economics-of-apandemic

UN ECA. United nation economic commission for Africa. (2020). COVID-19 in Africa: Protecting Lives and Economics. https://doi.org/10.18356/77f486e5-en

UNICEF (2020). UNICEF Ethiopia Socio-economic impacts of COVID-19. April, 4. https://www.unicef.org/ethiopia/media/2741/file/Soci o-economic\%20impacts\%20of\%20COVID-19.pdf

UNITED NATIONS. (2019). World Economic Situation and Prospects 2019.

https://www.un.org/development/desa/dpad/wpcontent/uploads/sites/45/WESP2019 BOOK-web.pdf

WB. WORLD BANK. (2019). Ending poverty, investing in opportunity. The World Bank Annual Report 2019 Washington, DC: World Bank. https://openknowledge.worldbank.org/handle/10986/ 32333

WEBER, A. (2020). Covid-19 in the Horn of Africa Gaining Trust in a Crisis. 20. Stiftung Wissenschaft und Politik - German Institute for International and Security Affairs, SWP. SWP Comment. No.20 May 2020. https://www.swpberlin.org/fileadmin/contents/products/comments/202 0C20_HornofAfrica.pdf

WORLDOMETER. (2020). Coronavirus Update (Live): Cases and Deaths from COVID-19 Virus Pandemic. In Worldometer. https://www.worldometers.info/coronavirus/ 